\title{
Editorial: Queensland modernisms
}

\author{
Jessica Gildersleeve \\ jessica.gildersleeve@usq.edu.au
}

To posit Queensland's modernism may seem like an oxymoron. Queensland is often the butt of the southern states' jokes. North of its more cultured and intellectual sibling-states (or so popular perception would have it), Queensland is 'backward', naïve, behind the times, provincial. According to this mythology, Brisbane is a glorified country town, Queenslanders refuse daylight saving for the sake of their very sensitive cows and curtains, and there is very little 'culture' to mention.

Queensland, in other words, is subject to regional prejudice. It is prejudice, moreover, that relies on a romantic tradition of Australian literature and culture - Queensland offers the nineteenth-century bush narrative as a contrast to the urban modernity of the southern capital cities. Indeed, as I have noted previously, 'Queensland, in this reading, is subject to the Orientalist discourse of an Australian national identity in which the so-called civilisation of the south-eastern urban capitals necessitates a dark "other"' (Gildersleeve 2012: 205).

By the same token, Queensland, as Thea Astley and others have had it, has always cultivated a sense of its own 'difference'. For Patrick Buckridge (1995: 30), this is best understood as 'a different sense of distance, different architecture, a different apprehension of time, a distinctive preoccupation with personal eccentricity, and ... a strong sense of cultural antitheses'. Buckridge and Belinda McKay begin their seminal study, By the Book: A Literary History of Queensland by exploring some of these differences and contradictions (2007: 1-4). What the essays in this special issue suggest, however, is that this difference is perhaps something more like Jacques Derrida's différance, an eternal deferral of meaning in the grand play of Queensland's shifting identity. The goal of this issue is to trouble existing narratives by engaging with the interdisciplinary and multidisciplinary construction and representation of modernism and modernity as it has appeared in Queensland in order to put Queensland (back) on the modernist map.

All of this is critical to our understanding of the emergence of modernism in Australia more generally. In their introduction to Regional Modernisms, Neal Alexander and James Moran (2013: 1) point out that a 'powerful and well-rehearsed narrative about modernism defines it as essentially metropolitan and internationalist in character, recalling that the majority of high-modernist writers and artists were exiles or émigrés, and that their texts are conspicuously polyglot, heteronomous, and fashioned from diverse cultural materials. They add: 'Modernism is, by definition, liberated from provincialism and local allegiances, caught up in an ambivalent but creatively productive relationship with the fluctuating currents of modernity and modernization.' Despite its perceived provincialism, the articles collected in this special issue show that Queensland was a critical site of modernist sentiment and 
production from the turn of the twentieth century, as shown in Belinda McKay's conceptualisation of 'proleptic modernism' in the work of Rosa Praed and Francis Adams, and stretching until the middle decades of the twentieth century, discussed in Jim Berryman's work on modernist poetry at mid-century, Kay Ferres's study of David Malouf's novel of World War I, Fly Away Peter (1982), and in Lisa Daunt's exploration of Brisbane church design during the 1960s.

Place has always been of critical interest to modernists and their critics. In modernist literature and art, the city returns again and again as the paradoxical symbol of modernist alienation and proximity - perhaps most famously Virginia Woolf's Mrs Dalloway (1925) and James Joyce's Ulysses (1922) — while escape from these urban centres exhibits the period's pastoral nostalgia, as in a number of D.H. Lawrence's works. It is place, too, that characterises Queensland modernism, as Queensland's particular 'difference' impacts not only the shaping of that place in public and private buildings and spaces, but also the stories and histories of the Queensland people as they navigate and dwell within those spaces, finding and making 'the new'. Given this interest in place and space in modernist studies, it is perhaps no surprise that several of the essays collected here draw on Susan Stanford Friedman's recent and influential work on 'planetarity', in which she seeks to trouble existing definitions of modernism and modernities as concerned primarily with formal innovation in the Western world (2010). This special issue on Queensland modernisms can be seen as part of this transnational turn in global modernist studies, heralded by Friedman's work, and signifying the increasing overlap between our understandings of the modern and the postcolonial, two terms most often associated with Australian history and culture. If it is true, as Friedman (2010: 475) puts it, that 'Every modernity has its distinctive modernism', then this special issue puts forward the distinction or difference of at least some characteristics of Queensland's modernism.

The articles collected here, written by both emerging and established scholars in the fields of Queensland studies and modernist studies, are naturally collected in two distinct strands. The first relates to the importance of buildings and place. Much of Brisbane's architecture developed in response not only to its sub-tropical climate (typified by Karl Langer's use of pergolas, louvres and site orientation) but also to post-war austerity (Hollander 1998: 72-4). Paying attention to modernist spaces as varied as swimming pools (Gosseye and Hampson) and churches (Daunt), these essays are interested in the ways modernity emerges from, and is bound up with, our particular social and environmental context.

The second strand is concerned with Queensland's literary modernism. Addressing poetry, fiction and plays from across the twentieth century, these essays explore the ways in which Queensland writers develop their own sense of modernism, often quite separately from the dominant tradition of European modernism. This is seen to be particularly true in Richard Fotheringham's study of Pat Hanna's 'digger play', Louis XI, published here in full for the first time; and sometimes in resistance to lingering concepts of Queensland provincialism in the first part of the century, as in Buckridge's reading of pre-World War II writing in Brisbane. Where these two approaches intersect, of course, is in telling the stories and the histories of the socalled 'sunshine state'. All of these essays, then, are interested in thinking through the different ways by which modernism makes meaning in a variety of social and historical contexts in the region. By way of tracing these across disciplines rather 
than maintaining the disciplinary distinctions that emerged here, I have elected to organise the papers chronologically in terms of their historical focus. In this way, these essays present the shifting and changing picture of Queensland's modernity in two of its most prominent forms: architecture and literature.

This set of perspectives, of course, indicates a number of opportunities to pursue Queensland modernisms in other forms. In particular, this issue does not engage with the modernism of Indigenous art (noted by McLean 2013), or with the modernity of music in Queensland- two areas in which one might expect to trace significant innovations associated with the modern period. Such opportunities for further research should be taken up as an extension of this issue, and I hope that the essays collected here provoke such new thinking about Queensland's modernisms.

In addition to the essays collected in this special issue, for the first time Queensland Review is also pleased to present a 'virtual issue', comprising nine articles published throughout the journal's history, which engage with the topic of Queensland's modernity. In their attention to such fields as art, cinema and cultural relations in particular, these essays not only go some way towards filling the gaps in the current issue, but also refer readers to the long history of discussion around Queensland's modernity that has taken place throughout the journal's history. Michael Levenson (2006: 1) asserts that a 'coarsely understood Modernism is at once an historical scandal and a contemporary disability'. This special issue of Queensland Review aims to go some way towards redressing that problem as it manifests in our state.

\section{References}

Alexander Neal and Moran James (eds) 2013. Regional modernisms. Edinburgh: Edinburgh University Press.

Buckridge Patrick 1995. 'Queensland literature: The making of an idea'. Queensland Review 2(1): 30-41.

Buckridge Patrick and McKay Belinda (eds) 2007. By the book: A literary history of Queensland. Brisbane: University of Queensland Press.

Friedman Susan Stanford 2010. 'Planetarity: Musing modernist studies'. Modernism/modernity 17(3): 471-99.

Gildersleeve Jessica 2012. 'Trauma, memory and landscape in Queensland: Women writing a "new alphabet of moss and water"'. Queensland Review 19(2): 205-16.

Hollander Robyn 1998. 'Modernism, austerity and the Queensland Housing Commission, 1945-59'. Journal of Australian Studies 22(57): 72-82.

Levenson Michael 2006. 'Introduction'. In Michael Levenson (ed.), The Cambridge companion to modernism. Cambridge: Cambridge University Press, pp. 1-8.

McLean Ian 2013. 'Mysterious correspondence between Charles Baudelaire and Tommy McRae: Reimagining modernism in Australia as a contact zone'. Australian and New Zealand Journal of Art 13(1): 70-89. 